\title{
Managerial Power, Earnings Management and Investment Efficiency
}

\author{
Shuang Li \\ Beijing Jiaotong University, China
}

Keywords: earnings management; managerial power; investment efficiency

\begin{abstract}
This paper empirically examines the relationship between earnings management and investment efficiency of listed companies in Shenzhen and Shanghai from 2011 to 2016 target observation period. In addition, managerial power is added as a governance factor to examine the influence of that on the relationship between earnings management and investment efficiency. The results show that earnings management and managerial power have a negative effect on investment efficiency, and managerial power can mitigate inefficient investment caused by earnings management. Further research shows that earnings management and managerial power can significantly aggravate the non-efficiency investment of manufacturing companies, but the impact on non-manufacturing companies is not obvious.
\end{abstract}

\section{Introduction}

Investment is the core driver of corporate wealth growth and the source of cash flow growth. High-quality investment not only is the basis for the company's continuing operations and long-term development, but also promotes the speed and quality of economic development. However, in real economic activities, the investment decisions of enterprises are often influenced by many factors, among which the agency problems and information asymmetry are the main factors. High-quality accounting information can reduce the information risk, thereby reducing non-efficiency investment. There are not many studies on the relationship among earnings management, managerial power and investment efficiency at home and abroad. Therefore, the paper will study the relationship among the three variables. Besides, considering the different operating conditions of manufacturing and non-manufacturing industries, this paper performed a classification study by industry.

\section{Research Hypothesis}

\subsection{Earnings Management and Investment Efficiency.}

At present, domestic and foreign scholars have conducted a lot of research on the relationship between earnings management and investment efficiency. From the analysis of the existing literature, we can see that high-quality surplus information can provide reliable and relevant information that helps investors make correct decisions (Savov, 2006, McNichols, 2008), reduce the adverse selection, and prevent inefficient investments (Qi Mingxia, 2017). In addition, investors read the high-quality surplus information to reduce the information disadvantage (Ren Chunyan, 2012), increase the ability to motivate and supervise the managers, suppress the agency conflicts caused by moral hazard, restrain inefficient investment, and ensure that their willingness to invest meets the goal of maximizing shareholder value. Therefore, this paper proposes the following hypothesis:

Hypothesis 1: The greater the level of earnings management, the easier it is to generate inefficient investments.

\subsection{Managerial Power and Investment Efficiency.}

Domestic and foreign scholars hold different views on the relationship between managerial power and investment efficiency. From the perspective of agency theory, when managers have more power, they may choose inefficient investment projects for personal interests (Lipton, 1992, Gao Xinzhi, 
2015 and He Chen, 2015). But the best contract theory holds that the greater the managerial power, the higher the ability to fully allocate resources and the higher the investment efficiency (Shleifer and Vishny, 1986, Tang Xuehua, 2015). However, most of the current research results are more inclined to agency theory. Therefore, this paper proposes the following hypothesis:

Hypothesis 2: The greater the power of management, the easier it is to generate inefficient investments.

\subsection{Earnings Management, Managerial Power and Investment Efficiency.}

The manager is responsible for the specific management of the company on behalf of the shareholders on the basis of the delegation relationship. The shareholders assess the managers through the accounting information to determine whether the contracts are to be continued. Therefore, the manager will implement earnings management in order to meet the performance requirements. When managerial power is greater, the degree of supervision of the board of directors will be weakened, which will increase the management incentives for earnings management (Liu Huilong, 2014, Xiao Lulu, 2017). Therefore, this paper proposes the following hypothesis:

Hypothesis 3: Management power can increases the positive impact of earnings management on inefficient investments.

\section{Empirical Research Design}

\subsection{Sample Selection and Data Sources.}

This paper selects A-share listed companies in Shenzhen and Shanghai for the period of 2011-2016 as the research object. In order to ensure the validity of the data and eliminate the impact of extreme values on model estimation, this paper filters the data according to the following criteria: (1) Excluding enterprises such as ST, *ST, and PT in any year during the study period. (2) Excluding financial companies. (3) Excluding companies with abnormal or missing variable values. In the end, there were 1,670 listed companies.

\subsection{Measurement of Relevant Variables.}

(1) Investment efficiency. This paper uses Richardson's (2006) model to estimate investment efficiency. The specific model is as follows:

$$
\begin{aligned}
& \text { Inv }_{i, t}=\beta_{0}+\beta_{1} \text { Growth }_{i, t-1}+\beta_{2} \text { Lev }_{i, t-1}+\beta_{3} \text { Cash }_{i, t-1}+\beta_{4} \text { Age }_{i, t-1}+\beta_{5} \text { Size }_{i, t-1} \\
& +\beta_{6} \text { Returns }_{i, t-1}+\beta_{7} \text { Inv }_{i, t-1}+\sum \text { Year }+\sum \text { Industry }_{+} \varepsilon_{i, t}
\end{aligned}
$$

Inv represents the new investment, Growth represents the investment opportunity, Lev represents the asset-liability ratio, Cash represents the cash ratio, Age represents the years of listing, Size represents the size of companies, and Returns represents the annual return of the stock. $\varepsilon$ represents the residual of the model. The absolute value represents the investment efficiency. The larger the value, the lower the investment efficiency.

(2) Earnings management. This paper uses the revised Jones model to estimate the degree of earnings management. The specific model is as follows:

$$
\begin{array}{r}
\frac{T A_{t}}{\text { Asset }_{t-1}}=\alpha_{1} \frac{1}{\text { Asset }_{t-1}}+\alpha_{2} \frac{\Delta R E V_{t}}{\text { Asset }_{t-1}}+\alpha_{3} \frac{P P E_{t}}{\text { Asset }_{t-1}}+\mu \\
\text { el2 }=\frac{\text { TAt }_{t}}{\text { Asset }_{t-1}}-\left[\hat{\alpha}_{1} \frac{1}{\text { Asset }_{t-1}}+\hat{\alpha}_{2} \frac{\left(\Delta R E V_{t}-\Delta R E C_{t}\right)}{\text { Asset }_{t-1}}+\hat{\alpha}_{3} \frac{P P E_{t}}{\text { Asset }_{t-1}}\right]
\end{array}
$$

TA represents the total accruals, Asset represents the total assets, $\triangle \mathrm{REV}$ represents the increase in operating income, $\triangle \mathrm{REC}$ represents the increase in accounts receivable, and PPE represents the fixed assets. The absolute value of el 2 represents the degree of earnings management. The larger the value, 
the higher the level of earnings management.

(3) Managerial power. The power of management is the sum of the values of the three dummy variables of the integration of two position (dual), manager's shareholding (msh), and the degree of equity dispersion (disp). The higher the value, the greater the power of management.

The specific variables are defined in Table 1.

Table 1 Variable definition and description

\begin{tabular}{|c|c|c|c|}
\hline & Variable name & Variable symbol & Variable description \\
\hline $\begin{array}{c}\text { Dependent } \\
\text { variable }\end{array}$ & investment efficiency & absel1 & absolute value of $\varepsilon$ \\
\hline \multirow{5}{*}{$\begin{array}{l}\text { Independe } \\
\text { nt variable }\end{array}$} & earnings management & absel2 & absolute value of el2 \\
\hline & \multirow{4}{*}{ managerial power } & dual & $\begin{array}{l}1 \text { represents the integration of two position, } \\
\text { otherwise } 0\end{array}$ \\
\hline & & msh & $\begin{array}{c}1 \text { represents the management holds shares, } \\
\text { otherwise } 0\end{array}$ \\
\hline & & disp & $\begin{array}{l}1 \text { represents the shareholding ratio of the largest } \\
\text { shareholder/the sum of the shareholding ratios } \\
\text { of the second to the tenth largest shareholders } \\
\text { less than } 1 \text {, otherwise } 0\end{array}$ \\
\hline & & power & dual+msh+disp, value are $0,1,2,3$ \\
\hline \multirow{6}{*}{$\begin{array}{c}\text { Control } \\
\text { variables }\end{array}$} & company size & size & the natural logarithm of total assets \\
\hline & equity structure & first & the shareholding ratio of the largest shareholder \\
\hline & board size & $\mathrm{dn}$ & the number of board members \\
\hline & board independence & idr & $\begin{array}{l}\text { the proportion of independent directors in the } \\
\text { board }\end{array}$ \\
\hline & $\begin{array}{l}\text { cash flow from operating } \\
\text { activities }\end{array}$ & cfo & $\begin{array}{l}\text { Net cash flow of operating activities / total } \\
\text { assets }\end{array}$ \\
\hline & $\begin{array}{l}\text { ultimate controller's } \\
\text { nature }\end{array}$ & soe & 1 represents state-owned enterprise, otherwise 0 \\
\hline
\end{tabular}

\subsection{Regression Model.}

In order to test the above three hypotheses, the following models are constructed:

$$
\begin{aligned}
& \text { absel }_{i, t}=\beta_{0}+\beta_{1} \text { absel }_{i, t}+\beta_{2} \text { first }_{i, t}+\beta_{3} d n_{i, t}+\beta_{4} i d r_{i, t}+\beta_{5} \text { cfo }_{i, t}+\beta_{6} \text { lev }_{i, t} \\
& +\beta_{7} \text { soe }_{i, t}+\beta_{8} \text { size }_{i, t}+\beta_{9} \text { tat }_{i, t}+v_{i, t} \\
& \text { absel }_{i, t}=\beta_{0}+\beta_{1} \text { power }_{i, t}+\beta_{2} \text { first }_{i, t}+\beta_{3} d n_{i, t}+\beta_{4} i d r_{i, t}+\beta_{5} c f o_{i, t}+\beta_{6} \text { lev }_{i, t} \\
& +\beta_{7} \text { soe }_{i, t}+\beta_{8} \text { size }_{i, t}+\beta_{9} \text { tat }_{i, t}+v_{i, t} \\
& \text { absel1 }=\beta_{0}+\beta_{1} \text { absel }_{i, t}+\beta_{2} \text { power }_{i, t}+\beta_{3} \text { power } * \text { absel } 2_{i, t}+\beta_{4} \text { first }_{i, t}+\beta_{5} d n_{i, t} \\
& +\beta_{6} i d r_{i, t}+\beta_{7} \text { foo }_{i, t}+\beta_{8} \text { lev }_{i, t}+\beta_{9} \text { soe }_{i, t}+\beta_{10} \text { size }_{i, t}+\beta_{11} \text { tat }_{i, t}+v_{i, t}
\end{aligned}
$$

\section{Analysis of Empirical Results}

\subsection{Descriptive Statistical Analysis.}

It can be seen from Table 2 that the average value of absel 1 and absel 2 are 0.03 and 0.068 , which means that the average inefficient investment scale in the sample is $3 \%$ of the total assets, and the average value of earnings management is $6.8 \%$ of the total assets of the previous period. The standard deviation are 0.032 and 0.106 , which shows that there are big differences in investment efficiency and 
earnings management between sample companies. The average power is 1.122 , which indicates that the level of the managerial power of sample enterprises is generally small, and the standard deviation of power is 0.907 , indicating that the difference of power is big.

\subsection{Correlation Analysis}

In order to ensure the validity of the estimated parameters, Pearson correlation analysis was performed on the variables (The results are not shown in this paper). The relationship between inefficient investment and earnings management and managerial power is consistent with expectations. At the same time, collinearity among other variables is not serious.

Table 2 Descriptive statistical analysis

\begin{tabular}{ccccc}
\hline & mean & sd & min & max \\
\hline absel1 & 0.03 & 0.032 & $7.76 \mathrm{e}-06$ & 0.257 \\
absel2 & 0.068 & 0.106 & $2.29 \mathrm{e}-06$ & 3.426 \\
power & 1.122 & 0.907 & 0 & 3 \\
first & 0.357 & 0.152 & 0.086 & 0.751 \\
dn & 8.903 & 1.777 & 5 & 15 \\
idr & 0.371 & 0.053 & 0.333 & 0.571 \\
size & 22.2 & 1.266 & 19.918 & 26.054 \\
cfo & 0.043 & 0.072 & -0.167 & 0.241 \\
soe & 0.483 & 0.5 & 0 & 1 \\
\hline
\end{tabular}

\subsection{Analysis of Empirical Results.}

From model 3.3 in Table 3, it can be seen that the coefficient of earnings management is significant at the level of $1 \%$, indicating that the level of earnings management is significantly positively correlated with non-efficiency investment, so hypothesis 1 is verified. The coefficient of managerial power is significant at the level of $10 \%$ of model 3.4, indicating that managerial power is significantly positively correlated with investment efficiency, and hypothesis 2 is verified. But the impact is small. Their interaction item is negatively correlated with investment efficiency at the level of $10 \%$ of model 3.5 , indicating that managerial power can, to a certain extent, mitigate the positive impact of earnings management on inefficient investment, and hypothesis 3 has not been verified.

Table 3 Regression results of the three models

\begin{tabular}{cccc}
\hline variables & 3.3 & 3.4 & 3.5 \\
\hline cons & $0.0703^{* * *}$ & $0.0716^{* * *}$ & $0.0699^{* * *}$ \\
absel2 & $(10.14)$ & $(10.31)$ & $(10.05)$ \\
& $0.0182^{* * *}$ & & $0.0264^{* * *}$ \\
power & $(6.05)$ & $0.0007^{*}$ & $(4.24)$ \\
& & $(1.69)$ & $0.0011^{* *}$ \\
power*absel2 & & $(2.41)$ \\
& & & $-0.0166^{*}$ \\
first & 0.00002 & $0.00004^{*}$ & $(-1.72)$ \\
dn & $(1.03)$ & $(1.85)$ & 0.00004 \\
& $0.0007^{* * *}$ & $0.0006^{* * *}$ & $(1.64)$ \\
idr & $(3.14)$ & $(3.03)$ & $0.0007^{* * *}$ \\
& $0.0146^{* *}$ & $0.0137^{* *}$ & $(3.19)$ \\
size & $(2.21)$ & $(2.06)$ & $0.0146^{* *}$ \\
& $-0.002^{* * *}$ & $-0.002^{* * *}$ & $(2.21)$ \\
cfo & $(-7.29)$ & $(-7.36)$ & $-0.002^{* * *}$ \\
& $0.0249^{* * *}$ & $0.0194^{* * *}$ & $(-7.43)$ \\
soe & $(5.31)$ & $(4.21)$ & $0.0253^{* * *}$ \\
& $0.006^{* * *}$ & $0.0059^{* * *}$ & $(5.38)$ \\
Adjusted $R^{2}$ & $(8.67)$ & $(8.32)$ & $0.0056^{* * *}$ \\
& 0.0368 & 0.0336 & $(7.93)$ \\
& & & 0.0372 \\
\hline
\end{tabular}

Note: ${ }^{* * *},{ }^{* *}$ and $*$ represent significant at the $1 \%, 5 \%$ and $10 \%$ levels, respectively 


\subsection{Classification Study by Industry.}

Previous studies did not discuss the relationship between managerial power, earnings management, and investment efficiency by industry. Therefore, this paper divides the sample into manufacturing samples and non-manufacturing samples for regression. The regression results are shown in Table 4.

From the regression results, it can be seen that for manufacturing companies, earnings management and non-efficiency investment are significantly positively correlated at the levels of $1 \%$, indicating that the higher the level of earnings management, the more inefficient the investment in the manufacturing companies. While the managerial power and inefficient investment are significantly positively correlated at the levels of $1 \%$, indicating that the grater the power of management, the more serious the inefficient investment. Its interaction items and inefficient investment are significantly negatively correlated at the levels of $1 \%$, indicating that management power can ease inefficient investment caused by earnings management. For non-manufacturing enterprises, earnings management and non-efficiency investment are not significant, indicating that earnings management has no significant effect on investment efficiency, and managerial power is not significantly correlated with investment efficiency. While the interaction item is positively correlated with the non-efficient investment at the $1 \%$ level.

Table 4 Regression results of classification study by industry

\begin{tabular}{ccc}
\hline variables & manufacturing & non-manufacturing \\
\hline ccons & $0.0654^{* * * *}$ & $0.07 * * *$ \\
& $(6.68)$ & $(7.14)$ \\
absel2 & $0.0556^{* * *}$ & 0.0064 \\
& $(5.67)$ & $(0.81)$ \\
power & $0.0018^{* * *}$ & -0.0006 \\
& $(3.08)$ & $(-0.80)$ \\
power*absel2 & $-0.0493^{* * *}$ & $0.0428^{* * *}$ \\
& $(-4.50)$ & $(3.40)$ \\
first & 0.00005 & 0.00002 \\
& $(1.44)$ & $(0.50)$ \\
dn & 0.0003 & $0.0009^{* * *}$ \\
& $(1.04)$ & $(3.12)$ \\
idr & $0.0176^{* *}$ & 0.0096 \\
& $(2.01)$ & $(0.96)$ \\
size & $-0.0023^{* * *}$ & $-0.0022^{* * *}$ \\
& $(-5.06)$ & $(-4.68)$ \\
cfo & $0.0133^{* *}$ & $0.04 * * *$ \\
& $(2.00)$ & $(6.07)$ \\
soe & $0.0068^{* * *}$ & $0.0034^{* * *}$ \\
& $(7.33)$ & $(3.02)$ \\
Adjusted $R^{2}$ & 0.0311 & 0.0570 \\
\hline
\end{tabular}

Note: $* * *, * *$ and $*$ represent significant at the $1 \%, 5 \%$ and $10 \%$ levels, respectively

Therefore, from the above analysis, it can be concluded that earnings management and managerial power have a significant positive impact on the inefficient investment of manufacturing companies. Managerial power can mitigate the positive effect of earnings management on inefficient investment, and earnings management and managerial power both have no significant effect on non-efficiency investment of non-manufacturing companies.

\subsection{Robustness Test.}

In order to ensure that the conclusions are true and reliable, this paper uses Tobin Q instead of the operating income growth rate as an alternative variable to growth opportunities, recalculating the company's investment efficiency, and re-run the regressions. The conclusions obtained are the same as above, indicating that the conclusions in this paper are robust (The results are not shown in this article). 


\section{Conclusion}

This paper takes the A-share listed companies in Shenzhen and Shanghai from 2011 to 2016 as the research object, based on principal-agent theory, and studies the impact of earnings management on investment efficiency from the perspective of information quality. On this basis, managerial power has been added as a governance element, and the impact of managerial power on the relationship between earnings management and investment efficiency has been analyzed.

This paper got the following conclusions: First, earnings management has a significant positive impact on non-efficiency investments. The higher the level of earnings management, the more likely it is to lead to non-efficient investments, and the more pronounced is the performance in over-investment; second, managerial power also has a significant positive effect on non-efficiency investment, but its impact is small. Third, managerial power can ease the positive effect of earnings management on non-efficiency investment, especially to alleviate excessive investment. In addition, this paper further analyzed the sample companies by industry, and found that manufacturing companies with high levels of earnings management and high managerial power have a higher probability of inefficient investment, especially over-investment, and managerial power can ease the positive effect of earnings management on inefficient investment; and for non-manufacturing companies, earnings management and managerial power have no significant impact on investment efficiency.

\section{References}

[1] Lipton M, Lorsch J W. A Modest Proposal for Improved Corporate. Governance Business Lawyer, 1992, 68(1): 282-287.

[2] McNichols M F, Stubben S R. Does earnings management affect firm`s investment decisions? [J]. the Accounting Review, 2008, 83: 1571-1603.

[3] Shleifer A, Vishny R W. Large Shareholders and Corporate Control [J]. The Journal of Political Economy, 1986: 461-488.

[4] Savov S. Earnings management, investment, and dividend payments. SSRN Working Paper, 2006.

[5] Gao Xinzhi. Managerial Power, Free Cash Flow, and Investment Efficiency [J]. Research on Financial Development, 2015, (11): 18-25.

[6] He Chen, Luo Qi, Yu Qing. Empirical Analysis of Institutional Environment, Managerial Power, and Over-investment in Listed Companies [J]. Statistics and Decision, 2015, (08): 163-166.

[7] Liu Huilong, Wang Chengfang, Wu Liansheng. Allocation of decision power, earnings management and investment efficiency [J]. Economic Research, 2014, 49(08): 93-106.

[8] Ren Chunyan. The Economic Consequences of Earnings Management from the Perspective of Corporate Investment Efficiency: Empirical Evidence from Chinese Listed Companies [J]. Finance Research, 2012, 38(02): 61-70.

[9]Qi Mingxia. Research on the Effect of Earnings Management on the Investment Efficiency of Listed Companies in China [J]. Friends of Accounting, 2017, (04): 56-60.

[10] Tang Xuehua, Mao Xinshu, Guo Lite. Managerial Power and non-Efficiency Investment: Empirical Tests based on China's A-share Market [J]. East China Economic Management, 2015, 29(12): 128-133.

[11] Xiao Lulu, Hong Hong, Hu Huaxia. Managerial Power, Earnings Management and Investment Efficiency [J]. Finance and Accounting Monthly, 2017, (24): 18-24. 